\title{
Hepatotoxicity of Gasoline as an Environmental Pollutant on Albino Mice
}

\author{
By Nawal El-Ghazaly* \\ Awatef Ali $i^{\dagger}$ \\ Samir Dekinesh \\ Azza Sedky ${ }^{+}$ \\ Sanaa Kabeil ${ }^{\bullet}$
}

This study focuses on finding if the hazards produced by gasoline 90 (vehicle fuel in Egypt) are less than those produced by gasoline 80 in healthy Swiss albino mice. Sixty mice were equally divided into 3 groups: group one (control), group two (topically treated with $0.5 \mathrm{ml}$ gasoline $90 / \mathrm{kg} \mathrm{B}$.W.) and group three (topically treated with $0.5 \mathrm{ml}$ gasoline $80 / \mathrm{kg} \mathrm{B.W.).} \mathrm{The} \mathrm{specimens} \mathrm{were} \mathrm{taken} \mathrm{after} 4$ and 8 weeks. Determination of bioaccumulation of some heavy metals, biochemical examination and a light microscopical study were performed. It was found that the accumulation of lead, cadmium and nickel in the liver had the following order lead > cadmium > nickel. After topically treated with gasoline 90 and 80 for 8 weeks, there was an increase in the activities of the serum liver function enzymes (alkaline phosphatase, alanine aminotransferase and aspartate amino transferase) and adenosine deaminase and a decrease in the total protein content of the liver homogenate. There were pathological changes which were more pronounced by treatment with gasoline 80 than with gasoline 90 depending upon treatment duration from 4 to 8 weeks. After 4 weeks of topically treating mice with gasoline 90 , cellular infiltration, dilatation of blood sinusoid and cytoplasmic vaculation were demonstrated. After 8 weeks the liver architecture of the mice was disrupted with liquid infiltration and the presence of foamy areas. After 4 weeks of topically treating mice with gasoline 80, we observed a shrinking of the blood sinusoid, hypatocyte vaculation with pyknotic nuclei and different stages of karyolysis. After 8 weeks, there was a noticeable hypatocyte degeneration and complete disappearance of blood sinusoids in the liver sections of the mice.

Keywords: Bioaccumulation, Gasoline, Histopathology, Liver, Mice, Physiology

\section{Introduction}

Various types of hydrocarbons that are present in the environment possess immune toxicity and cause either structural, functional or compositional changes in various components of the immune system (Bahadar et al., 2014).

\footnotetext{
*Alexandria University, Egypt.

${ }^{\dagger}$ Professor, Alexandria University, Egypt.

* Alexandria University, Egypt.

+ Alexandria University, Egypt.

- Alexandria University, Egypt
} 
These modulate the normal physiology of the immune system in humans and experimental animals which compromise the host defense mechanisms (Mokarizadeh et al., 2015). The aromatic fraction of the gasoline contains some highly toxic hydrocarbons, such as benzene, among the single-ring aromatics and benzo (a) pyrene, among the polycyclic aromatic hydrocarbons. About 110 million people are exposed to gasoline constitutes during refueling at gasoline stations (Wixtrom and Brown, 1992). Employees in gasoline companies may be exposed to gasoline during the production and transportation process. Exposure to gasoline may occur to motor mechanics in workshops and to gasoline attendants and the general population during refueling at gas stations. Spills, leaks or improper disposal of gasoline can cause contamination of soil, ground water, surface water and air. Gasoline enters into the body orally (accidental), transdermally and by inhalation (Guo et al., 2003). Benzene requires to be metabolized to induce its effects and its metabolism plays a critical role in the toxicity (Snyder and Hedli, 1993). The major hepatic metabolites of benzene are phenol, catecol and hydroquinone (Cooper and Snyder, 1988). Benzene exposure affects a variety of organs such as the kidney, liver, testis and brain (Dundaroz et al., 2003). Also it is associated with various hematotoxins and carcinogens (Khadiga et al., 2014). It can cause negative health effects in humans depending upon both the amount and duration of the exposure (Dere et al., 2003).

The liver regulates various metabolic functions in mammalian systems and hepatic damage is associated with the distortion of these metabolic functions. The liver tissue is reported to among the tissues with a high regenerative capacity (Khan and Mudan, 2007). Bogiswariy et al. (2008) reported that the liver has functions in hydrocarbon inactivation, nutrient storage, the release of products of catabolism from other tissues and the production of bile, which favor the digestion of fatty acids and carry conjugated metabolites of toxicants for excretion.

Different chemical agents, including gasoline vapor constituents, are known to be hepatotoxic (Uboh et al., 2007a) and hematotoxic (Uboh et al., 2007b). In experimental rat models, exposure to gasoline vapor has also been reported to cause oxidative stress, which disturbs the antioxidant defense system and produces an alteration in lipid peroxidation (Uboh et al., 2007a).

The potential health hazards associated with chronic or sub chronic exposure to these ubiquitous pollutants in the environment has attracted the attention of the general public and the scientific community. This study focuses on finding if the hazards produced by gasoline 90 (vehicle fuel in Egypt) are different than those produced by gasoline 80 . The liver and blood were chosen because they are sites for intense metabolism and detoxification. Unfortunately, they are often damaged by environmental toxins such as petroleum and its derivatives. 


\section{Materials and Methods}

\section{Materials \\ Experimental Animals}

Male Swiss albino mice (10 weeks old, weighting 20-25 g.) were used as experimental animals. They reared in metal cages of usual type $(30 \mathrm{~cm}$ length, $20 \mathrm{~cm}$ width and $15 \mathrm{~cm}$ high) with wood shavings as a substrate. The mice were allowed to acclimatize, one week before the initiation of the experiments, under normal laboratory conditions. They were allowed free access of a standard balanced laboratory diet (wheat, milk and carrot) and tap water.

\section{Experimental Compounds}

Gasoline was obtained from a fuel station in a 1 litter clean bottle. Gasoline concentrations of two different octane numbers were used: octane number 90 (green color) and octane number 80 (red color).

\section{$\underline{\text { Route of Administration }}$}

The topical exposure was done by shaving an area of the back skin of the mice $(3 \times 4 \mathrm{~cm})$. The animals were left at least $24 \mathrm{~h}$ after hair removal to ensure that no irritation occurred from the hair removal process. Gasoline liquid $(0.5$ $\mathrm{ml} / \mathrm{kg} \mathrm{B.W.})$ was dropped $(0.1 \mathrm{ml} /$ mouse/ day $)$ onto the shaved area. To minimize the exposure of the animal by inhalation, treatment was performed with cold gasoline $\left(4^{\circ} \mathrm{C}\right)$. Each animal was treated slowly to avoid any significant spillover and kept separately from the others until the gasoline had dried.

\section{Experimental Design}

Sixty mice were equally divided into 3 groups: group one (control, daily topical exposure to drop of tap water), group two (daily topically treated with $0.5 \mathrm{ml}$ gasoline $90 / \mathrm{kg} \mathrm{B.W.)} \mathrm{and} \mathrm{group} \mathrm{three} \mathrm{(daily} \mathrm{topically} \mathrm{treated} \mathrm{with} 0.5 \mathrm{ml}$ gasoline $80 / \mathrm{kg} \mathrm{B.W.).The} \mathrm{experiment} \mathrm{extended} \mathrm{for} 8$ weeks.

\section{Methods}

1-Physiological Studies: At the end of the experiment, blood samples were collected from the orbital sinus vein puncture for colorimetric kinetic determination of serum alkaline phosphatase activity (Wan et al., 2007), determination of alanine aminotransferase (ALT) (Tietz, 1995), determination of aspartate aminotransferase (AST) (Burtis, 1999). Also the liver homogenate for determination of activity of adenosine deaminase (Burtis, 1999) and determination of total protein content (Lowry's method, 1951).

2-Determination of Bioaccumulation of Some Heavy Metals: After 4, 8 weeks the liver was excised and the concentration of lead, cadmium and nickel were determined by using an electron dispersive X-ray apparatus attached to a scanning electron microscope (Leo - UIF: Leo438VP) - Faculty of Science, Alexandria University. 
3-Light Microscopical Study: After 4 and 8 weeks ,small portions of the liver from the control and treated groups was excised, fixed at room temperature overnight in $10 \%$ formalin solution then processed to be stained routinely with haematoxylin and Eosin according to Bancroft and Gamble (2002).

4-Statistical Studies: The obtained measurements were analyzed using the SPSS program to evaluate the significance of the difference between the mean value of the measured parameters in the respective tested groups and the control-group. A significant change was accepted at $\mathrm{P} \leq 0.05$.

\section{Results}

Physiological Results (Table 1)

Alkaline Phosphatase (ALP) in Serum: ALP activity was significantly differed $(\mathrm{P} \leq 0.05)$ between the control-group and both the treated groups $(\mathrm{F}=$ $13.318, \mathrm{P}=0.001)$ while there was a insignificant difference $(\mathrm{P} \leq 0.05)$ between ALP activity in gasoline 90-group and gasoline 80-group.

Alanine Amino Transferase (ALT) in Serum: ALT activity was significantly different $(\mathrm{P} \leq 0.05)$ between the control-group and both the treated groups $(\mathrm{F}=5.014, \mathrm{P}=0.026)$ while there was an insignificant difference $(\mathrm{P} \leq 0.05)$ between the ALT activity in the gasoline 90-group and the gasoline 80-group.

Aspartate Amino Tansferase (AST) in Serum: AST activity was significantly different $(\mathrm{P} \leq 0.05)$ between the control-group and both the treated groups $(\mathrm{F}=11.222, \mathrm{P}=0.002)$. There was an insignificant difference $(\mathrm{P}$ $\leq 0.05)$ between the AST activity in the gasoline 80-group and the gasoline 90group.

Adenosine Deaminase (ADA) in Liver Homogenate: There were significant differences $(\mathrm{P} \leq 0.05)$ between the control-group and both the treated groups $(\mathrm{F}=12.846, \mathrm{P}=0.001)$. Also, there was significant difference $(\mathrm{P} \leq 0.05)$ in the ADA activity between the gasoline 90-group and the gasoline 80-group.

Total Protein Content in Liver Homogenate: There were significant differences $(\mathrm{P} \leq 0.05)$ between the control and both the treated groups $(\mathrm{F}=$ $3.145, \mathrm{P}=0.080)$. There was a insignificant difference $(\mathrm{P} \leq 0.05)$ between the gasoline 90 and the gasoline 80-group. 
Table 1. Effect of Topically Exposure of Male Mice to Gasoline 80 \& 90 on Some Physiological Parameters

\begin{tabular}{|c|c|c|c|c|c|c|}
\hline & & & Serum enzyn & mes & Liver hol & mogenate \\
\hline Experimen & ital group & ALP & $\mathbf{L}^{\prime}$ & $\mathbf{A} \mathbf{S}^{\prime}$ & ADA & Protein \\
\hline & 1 & 37 & 48 & 78 & 11.2 & 201 \\
\hline & 2 & 44 & 52 & 82 & 13.2 & 287 \\
\hline Control & 3 & 49 & 69 & 92 & 9.8 & 200 \\
\hline & 4 & 52 & 51 & 71 & 10.3 & 170 \\
\hline & 5 & 35 & 39 & 110 & 14.6 & 194 \\
\hline & Mean \pm S.E & $43.4 \mathrm{a} \pm 2.96$ & $51.8 \mathrm{a} \pm 4.37$ & $86.6 \mathrm{a} \pm 6.07$ & $11.82 \mathrm{a} \pm 0.81$ & $210.4 \mathrm{a} \pm 17.90$ \\
\hline & 1 & 93 & 99 & 129 & 27.2 & 149 \\
\hline Gasoline & 2 & 100 & 110 & 175 & 19.4 & 139 \\
\hline 90 topically & 3 & 80 & 84 & 221 & 15.8 & 148 \\
\hline treated & 4 & 75 & 72 & 219 & 14.3 & 172 \\
\hline mice & 5 & 66 & 53 & 191 & 20.6 & 162 \\
\hline & Mean \pm S.E & $82.8 \mathrm{~b} \pm 5.50$ & $83.6 \mathrm{~b} \pm 8.98$ & $187 b \pm 15.15$ & $19.46 \mathrm{~b} \pm 2.02$ & $154.0 \mathrm{~b} \pm 5.81$ \\
\hline & 1 & 69 & 68 & 195 & 39 & 137 \\
\hline Gasoline & 2 & 59 & 79 & 170 & 41 & 172 \\
\hline 80 topically & 3 & 46 & 86 & 200 & 18 & 156 \\
\hline treated & 4 & 75 & 95 & 108 & 29 & 170 \\
\hline mice & 5 & 82 & 57 & 115 & 30 & 190 \\
\hline & Mean \pm S.E & $66.2 b c \pm 5.65$ & $77 \mathrm{bc} \pm 5.98$ & $157.6 \mathrm{bc} \pm 17.51$ & $31.4 \mathrm{c} \pm 3.68$ & $165.0 \mathrm{~b} \pm 8.84$ \\
\hline & $\mathbf{F}$ & 13.318 & 5.014 & 11.222 & 12.846 & 3.145 \\
\hline & $\mathbf{P}$ & 0.001 & .026 & 0.002 & 0.001 & 0.080 \\
\hline
\end{tabular}

$\mathrm{p}$ : $\mathrm{p}$ value for $\mathrm{F}$ test (ANOVA)

F: F test $\mathrm{f}$ (ANOVA)

Different superscripts are significant. *: Statistically significant at $\mathrm{p} \leq 0.05$

Bioaccumulation of Some Heavy Metals (Table 2)

There was a significant difference between the lead concentration in the control-group and both the treated groups for 4 and 8 weeks $(\mathrm{F}=13.73, \mathrm{P}=$ 0.001). The cadmium concentration was significantly different between the control group and both treated groups for 4 and 8 weeks $(F=58.39, \mathrm{P}=0.001)$. The mean value of nickel concentration was significantly different between the control -group and the gasoline 80-group for 4 or 8 weeks $(\mathrm{F}=15.47, \mathrm{P}=$ 0.001) while there was no significant difference between the control-group and gasoline 90-group for 4 and 8 weeks. 
Table 2. Bioaccumulation of Some Heavy Metals (\% Total) in Liver of Mice Topically Treated with both Gasoline (90 and 80)

\begin{tabular}{cccc}
\hline EExperimental group & LLead & CCadmium & NNickel \\
\hline CControl & $0.07 \pm 0.07$ & $0.0 \pm 0.0$ & $0.03 \pm 0.03$ \\
\hline GGasoline 90/4 weeks & $1.0 \pm 0.46$ & $0.27 \pm 0.03$ & $0.33 \pm 0.09$ \\
\hline GGasoline 90/8 weeks & $2.80 \pm 0.40$ & $0.47 \pm 0.12$ & $0.30 \pm 0.06$ \\
\hline GGasoline 80/4 weeks & $4.30 \pm 0.72$ & $0.93 \pm 0.07$ & $0.57 \pm 0.09$ \\
\hline GGsoline 80/8 weeks & $3.47 \pm 0.46$ & $1.97 \pm 0.18$ & $1.50 \pm 0.29$ \\
\hline F (p) & 1 & $53.39 *(<0.001)$ & $5.47(<0.001)$ \\
\hline
\end{tabular}

F: $\mathrm{F}$ test $\mathrm{f}(\mathrm{ANOVA})$

$P: p$ value for $F$ test (ANOVA)

Different subscripts are significant.

*: statistically significant at $\mathrm{p} \leq 0.05$

\section{Light Microscopical Results}

Gasoline 90-Group: After 4 weeks, the impaction of liver sections demonstrated the presence of cellular infiltration, dilatation of blood sinusoids, and an increased number of binucleated hepatocytes (Figure 1). The hepatocytes appeared with cytoplasmic vacuolization especially perinuculated vacuole and irregular nuclei (Figure 2). After 8 weeks, the liver sections demonstrated more pathological changes than after 4 weeks, as an architecture disruption with cellular and liquid infiltration. Hepatocytes contained cytoplasmic vacuoles and karyolitic nuclei (Figure 3). Also, congested dilated blood sinusoid, increased number of shrinked nuclei of kupffer cells and the presence of foamy areas were recorded (Figure 4).

Gasoline 80-Group: Haematoxyline and eosin stained sections after 4 weeks revealed complete disappearance of liver architecture in some areas. This involved obvious cellular infiltration, shrinked blood sinusoids, vacuolization of hepatocyte with pyknotic nuclei and an increased number of binucleated hepatocytes (Figure 5). Figure 6 showed a foamy area, congested central vein and different stages of karyolysis ranging from pale nuclei to completely disappear. After, 8 weeks highly pathological changes appeared such as dilated portal vein, cellular infiltration around bile ductule, an increased number of binucleated cells and the noticeable degeneration of hepatocyte cytoplasm (Figure 7). Many areas appeared with a complete disappearance of blood sinusoids, hypertrophied kupffer cells and foamy areas (Figure 8). 
Light micrograph of liver section of male mouse topically exposed to gasoline 90 for 4 weeks, shows:

Figure 1. Increased Number of Binucleated Hepatocyte (Dashed Arrows) Cellular Infiltration (Star), Dilatation of Blood Sinusoid (Arrows). Central Vein $(C V)$ (H\&E Stain, X4)

Figure 2. Hepatocyte with Cytoplasmic Perinuclear Vacuolization (Dashed Arrow) and Irregular Nucleus. Dilatated Blood Sinusoid (Arrows) and Central Vein (CV) (H\&E Stain, X100)

Light micrograph of liver section of male mouse topically exposed to gasoline 90 for 8 weeks, shows:

Figure 3. Disappearance of Normal Liver Architecture with Liquid Infiltration (Circle), Cellular Infiltration (Star), Hepatocytes with Cytoplasmic Vacuolization and Karyolitic Nuclei (Arrows). Central Vein (CV) (H\&E Stain, X40)

Figure 4. Deformed Liver (Circle) with Congested Dilated Blood Sinusoid (Arrows) and Increased Number of Kupffer Cells with Shrinked Nuclei. Central Vein (CV) (H\&E Stain, X40)

Light micrograph of liver section of male mouse topically exposed to gasoline 80 for 4 weeks, shows:

Figure 5. Disappearance of Normal Liver Architecture with Shrinked Blood Sinusoids, Vacuolization of Hepatocyte with Pyknotic Nucleus (Arrow) and Cellular Infiltration (Star) (H\&E Stain, X40)

Figure 6. Congested Central Vein $(C V)$, Foamy Area and Ascending Order of Karyolysis (1, 2 and 3) (H\&E Stain, X100)

Light micrograph of liver section of male mouse topically exposed to gasoline 80 for 8 weeks, shows:

Figure 7. Increased Number of Binucleated Hepatocytes (Arrow), Cellular Infiltration (*) and Obvious Degeneration of Hepatocytes. Bile Ductule (Bd) Dilated Portal Vein (Pv) (H\&E Stain, X40)

Figure 8. Nearly Complete Disappearance of Blood Sinusoid with Severe Hepatocyte Degeneration, Increased Number of Binucleated Hepatocytes (Arrows), Foamy Area (Circle) and Hypertrophied Kupfer Cell (DashedArrows) (H\&E Stain, X100) 


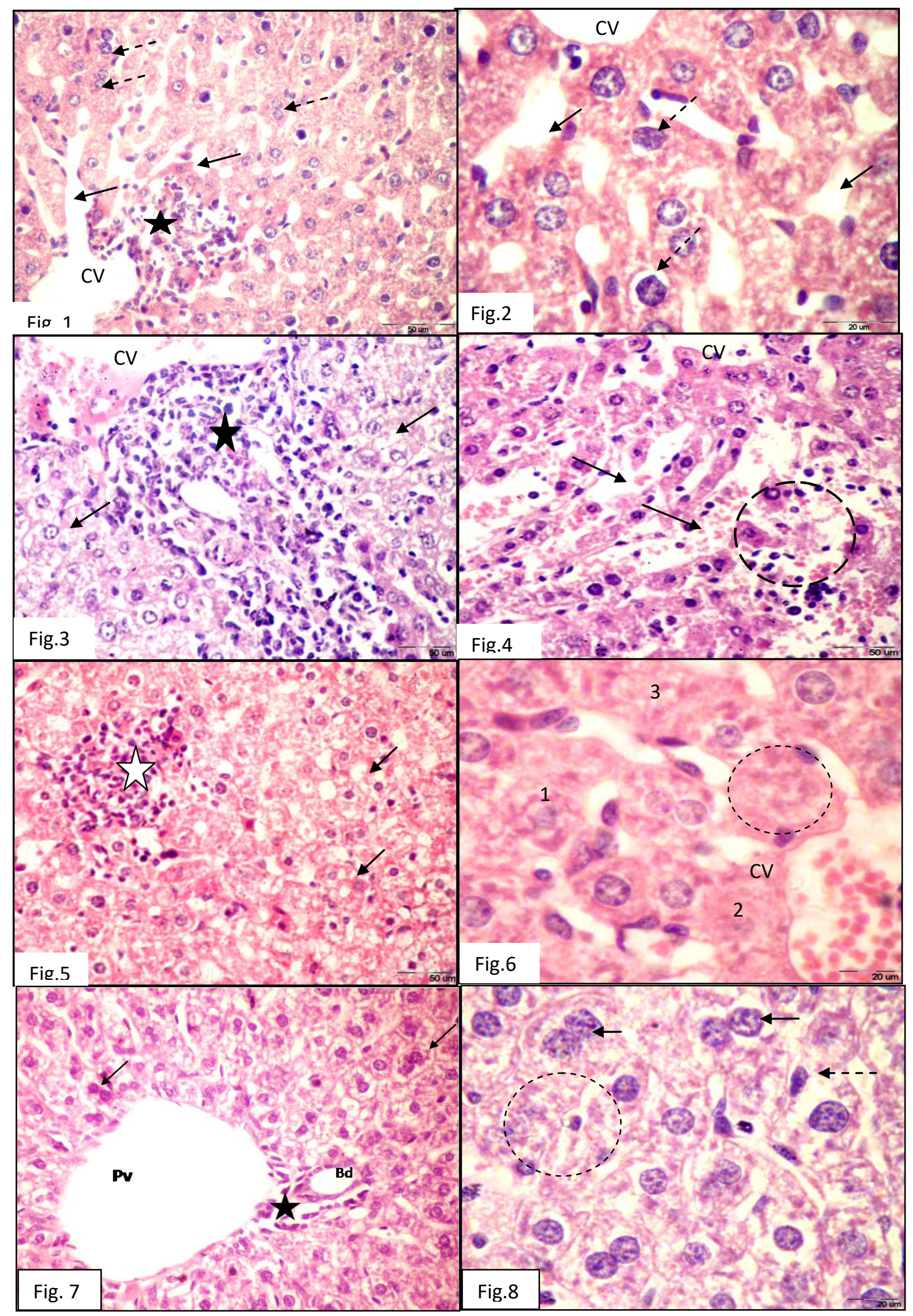




\section{Discussion}

The liver possesses enzymes and cofactors necessary for an unparalleled number of metabolic reactions. It is of vital importance in intermediary metabolisms and in the detoxification and elimination of toxic substances (Pratibha et al., 2004). Liver enzymes such as ALT, AST, and ALP are known as marker enzymes for the assessment of the functional integrity of the liver cells (Adaramoye et al., 2008). These enzymes are usually raised in an acute hepatotoxicity or mild hepatocellular injury, but tend to decrease with prolonged intoxication due to damage of the liver (Jaeger and Hedegaard, 2002). The present results indicated that there is a significant increase ( $\mathrm{P} \leq$ $0.05)$ in the activities of serum ALP, ALT and AST of the male mice topically treated with gasoline 90 and 80 for 8 weeks when compared to control.

Dere et al. (2003) demonstrated an increase in the enzyme activities of ALP, ALT and AST in different tissues of rats exposed to benzene. Also, AST and ALT increased significantly after 24 hours of benzene treatment (Park et al., 2008).

Iheoliaha et al. (2009) reported that female albino rats given water contaminated with $5 \%$ engine oil for a period of 21 days had a significant increase in the activity of the ALP serum enzyme. The mice that were allowed to drink water contaminated with diesel $1 \%(\mathrm{~V} / \mathrm{V})$ for 6 weeks had a significant increase in activities of ALP, ASP and ALT serum enzymes (Udem et al. 2009). Rat exposure to gasoline vapor for 6hr/day, 5 days/ week for 20 weeks caused a significant increase in the activity of the ALP, ALT and AST serums (Uboh et al., 2009). The increase in the levels of the enzymes was gasoline dose dependent (George and Adegoke, 2011). Rat exposure to gasoline vapor significantly $(\mathrm{P} \leq 0.05)$ increased the activities of the ALT and ALP serums; it also decreased the concentrations of serum total protein (Friday et al., 2012).

Since the heavy metals could not be degraded, they were deposited in different organs of the body where their bioaccumulation resulted in health risks (Agah et al., 2009). Also, when the animals were exposed to elevated levels of metals; it could absorb the bioavailable metals directly from the environment via the skin (Putte and Part, 1982). The metals are then transported by the blood stream which brings them to contact with the various tissues and their bioaccumulation causing toxicity on several organs and systems in the body (Young, 1995). The accumulation of heavy metals in liver tissue contributed to the presence of the metallothionein proteins which are synthesized in the liver tissues when the body is exposed to heavy metals and detoxifies them (Jobling, 1995). These proteins are thought to play an important role in protecting the liver from damage by heavy metal toxicants. Marked increases of metal concentrations in the liver indicated its relative critical importance for detoxification and release mechanisms (Salah El-Deen, 1999).This might explain the disruption of liver parameters after the benzene treatment in this study.

Vinodhini and Narayanan (2008) found that lead bioaccumulated in the different organs more than cadmium and nickel. This comes in agreement with 
the present results where the concentrations of $\mathrm{Pb}>\mathrm{Cd}>\mathrm{Ni}$ in the liver. The toxicity of the lead may be due to the fact that lead is a divalent cation, and it binds strongly to sulfhydral group proteins. Lead is toxic since it has the ability to mimic or complete calcium. At picomolar concentrations, lead competes with calcium for binding sites on cerebellar phosphokinase $\mathrm{C}$ and thereby affects neuronal signaling. It inhibits calcium entry into cells and enhances spontaneous neurotransmitter release, whereas stimulated release is inhibited (Bressler and Goldstein, 1991).

Smirjakova et al. (2005) pointed out that cadmium represents a serious industrial and environmental pollutant. It is a relatively volatile element and its presence is unwanted and harmful. An early manifestation of cadmium toxicity and carcinogenicity is due to the oxidative damage of tissues and DNA. The inhibition of antioxidant defenses and DNA repair mechanisms is caused by the inactivation of thiol groups in critical molecules by the oxidative effect of cadmium (Kasprzak, 2002).

Redox inactive metals, such as lead and cadmium deplete the major antioxidants of cells, particularly thiol containing antioxidants and enzymes and may cause an increase in the production of reactive oxygen species (ROS) which can over cells intrinsic antioxidant defenses, and lead to "oxidative stress". Cells under oxidative stress display various dysfunctions due to the lesions caused by ROS to lipid, proteins and DNA. It is suggested that the toxic effects of heavy metals is due to metal-induced oxidative stress in the cells (Ercal et al., 2001).

Many effects of nickel are due to the interference with the metabolism of essential metals such as $\mathrm{Fe}$ (II), $\mathrm{Zn}$ (II), $\mathrm{Cu}$ (II), $\mathrm{Mn}$ (II) and $\mathrm{Ca}$ (II) which can suppress the toxic and carcinogenic effects of nickel. The toxic functions of nickel probably result primarily from its ability to replace other metal ions in enzymes and proteins or to bind to cellular compounds containing O-, S- and $\mathrm{N}$-atoms such as enzymes and nucleic acids causing their inhibition (ScottFordsmand, 1997).

In this study, the activities of serum ALT, AST and ALP were significantly increased. Also, the values of the total protein and total albumin were statistically decreased following exposure to gasoline. The changes in biochemical parameters were substantiated by the histopathological changes, as ballooning degeneration, hepatocytes with pyknotic nuclei and lymphocytic infiltration (indicative and reflective of acute hepatocellular injury). These results are in agreement with the research of Uboh et al. (2007a) and Uboh et al. (2008) that showed severe adverse physiological and biochemical disturbances that affect the functional and structural integrity of the liver tissues in experimental animals after exposure to gasoline vapor.

Hamadouche et al. (2009) and Sharma et al. (2010) suggested that increase in ALP activity indicated the increased permeability, damage and/or necrosis of cells.

Friday et al. (2012) indicated severe histopathological changes, such as centrilobular hepatic necrosis, tissue fatty change, Kupffer cells, ballooning degeneration, and infiltrating lymphocytes. This suggested that the cellular 
integrity of the liver tissues was altered by the constituents of gasoline vapor, and hence the derangement of their cellular functions.

From the present study, it may be suggested that lead hepatotoxicity leads to vacuolization of the cells. This observation confirmed the study of Sharma et al. (2010), where oral treatment of mice with lead nitrate caused vacuolization of hepatocytes. The presence of cytoplasmic vacuoles in the toxicant exposed liver is due to the excessive accumulation of fat in the cytoplasm (Bogiswariy, 2008).

In addition to the cytoplasmic vacuolization, the present light preparation revealed the presence of inflammatory cellular infiltration in the liver of mice topically treated with gasoline 90 and 80 for 4 and 8 weeks. In this connection, the inflammatory response was reported by other workers such as Gökcimen et al. (2002), who revealed that the exposure of rats to $27.12 \mathrm{~Hz}$ magnetic field caused mixed cell infiltration in the liver parenchyma. Also, Carbon tetrachloride induced lobular inflammation in treated rats (Kumar et al., 2009).

Another pattern of liver damages observed in the present study was the presence of necrosis and foamy areas in liver of mice topically exposed to gasoline (90 and 80). Similar results were found in the liver of tropical freshwater fish (Astyanax sp.) after water borne and acute exposure to water soluble fraction of crude oil (Akaishi et al., 2004) and in the liver of albino rats after kept at a benzene station for 60 and 120 days, respectively (Abousalem et al., 2014). The necrosis in the liver is typical. Acute lesion and cellular death associated with this type of necrosis not only induces an inflammatory response, but also decreases the functional number of cells in the tissue with deleterious consequences for the organ function. In addition, pyknosis is a state when condensed nuclei are present in the hepatocytes and it might be due to the deposition of lipid and glycogen (Gökcimen et al., 2002).

In this study, it was estimated that the numerical density of binucleated hepatocytes was higher in the liver of mice topically exposed to gasoline 90 than that in those of the control mice. Similar results were obtained by Altunkaynak and Özbek (2009) who reported that a high population of binucleated hepatocytes is one criterion for chronic liver disease including cancer and is taught that it might have been the result of a compensatory mechanism in response to the decreased number of hepatocyte due to necrotic changes.

Park et al. (2008) reported that the liver of mice treated with benzene after $24 \mathrm{hrs}$ showed hepatocytes microbalooning and binucleated cells but treatment for 6 days showed hypertrophy of hepatocytes and enlargement of nuclei.

\section{Conclusions}

From data mentioned above, it can be concluded that, the changes observed (physiological and histological) are more exaggerated with intensive exposure and type of gasoline, i.e., severity of gasoline is duration dependent and more obvious in gasoline 80 than 90 . So human exposure to benzene in 
work environments is a global occupational health problem and blood picture tests should be done to detect the early effects of benzene exposure for human health security.

\section{Acknowledgments}

Our thanks to the scanning electron microscope unite- Faculty of ScienceAlexandria University for the skillful technical assistance.

\section{References}

Abousalem, M., Elgerwi, A., El-Mashad, A. 2014. Genotoxic and histotoxic effects of air pollutants at a benzene station on albino rats. International Journal of Basic \& Clinical Pharmacology, 3 (1):144-150.

Adaramoye, O., Osaimoje, D., Akinsanya, M., et al. 2008. Changes in antioxidant status and biochemical indices aft er acute administration of artemether, artemether-lumefantrine and halofantrine in rats. Basic Clin Pharmacol Toxicol, 102: $412-418$.

Agah, H., Leermakers, M., Elskens, M., Fatemi, S. and Boeyens, W. 2009. Accumulation of trace metals in the muscles and liver tissues of five fish species from the Persion Gulf. Environ. Monit. Assess, 157: 499-514.

Akaishi, F., Silva de Assis, H., Jakobi, S., Eiras-Srofella, D., St-Jean, S., Courtenay, S., Lima, E., Wagener, A., Scofield, A. and Oliveira Ribeiro, C. 2004. Morphological and Nerotoxicological findings in tropical freshwater fish (Asryanax Sp.). After waterborne and acute exposure to water soluble fraction (WSF) of crude oil. Arch. Environ. Contam. Toxicol ,46: 244-253.

Altunkaynak, B. and Özbek E. 2009. Overweight and structural alterations of the live in female rats fed a high-fat diet: a stereological and histological study. Turk $\mathbf{J}$ Gastrenterol, 20(2): 93-103.

Bahadar, H., Abdollahi, M., Maqbool, F., Baeeri, M. and Niaz, K. 2014. Mechanistic Overview of Immune Modulatory Effects of Environmental .Toxicants. Inflammation \& Allergy - Drug Targets, 13:382-386.

Bancroft, D. and Gamble, M. 2002. The theory and practice of histological technique. 5th edition. Churchil Living Stone. 75p.

Bogiswariy, S., Jegathambigai, R. and Marimuthu, K. 2008. Effect of acute exposure of cadmium chloride in the morphology of the liver and kidney of mice, intern. Conf. Environ. Res. Technol. (ICERT).

Bressler, J. and Goldstein, G. 1991. Mechanisms of lead neurotoxicity. Biochem. Pharmacol, 41: 479-84.

Burtis, A. 1999. Tietz Textbook of clinical chemistry, 3rd ed.

Cooper, K. and Snyder, R. 1988. In benzene carcinogenicity (Askoy, M., ed) pp. 3558, CRC Pres, Boca Raton, FL.

Dere, E., Gyborova, S. and Aydın, H. 2003. The effect of benzene on serum hormones and the activity of some enzymes in different tissues of rats. Acta Veterinaria, $53,: 87-101$. 
Dundaroz, M., Turkbay, T., Akay, C., Sarici, S., Aydin, A., Denli, M. and Gokcay, E. 2003. Antioxidant enzymes and lipid peroxidation in adolescents with inhalant abuse. The Turkish Journal of Pediatrics, 45: 43-45.

Ercal, N. Gurer-orhan, H. and Aykin-Burns, N. 2001. Toxic metals and oxidative stress part I: mechanisms involved in Metal-induced oxidative damage. Current Topics in Medicinal Chemistry, 1(6): 529-539.

Friday, E., Patrick, E., Henry, D. and Itoro, F., 2012. Hepatoprotective effect of vitamins $\mathrm{C}$ and $\mathrm{E}$ against gasoline vapor-induced liver injury in male rats. Turk $\mathrm{J}$ Biol, 36 : 217-223.

George, M. and Adegoke, O. 2011. Effect of Vitamin E on Biochemical Parameters in Albino Rats Treated with Gasoline .J. Sci. Res, 3 (3): 641-649.

Gökcimen, A, .Özgüner, F., Karaöz, E., Özen, S. and Aydin, G. 2002. The effect of melatonin on morphological changes in liver induced by magnetic field exposure in rats. Okajimas folia Anar. Jpn, 79(1): 25-32.

Guo, J., Wang, D. and Huang, H. 2003. Spontanos remiision of edema and regranulation of goblet cells in rat trachea after capsaicin - induced acute inflammation Anat Embryol, 206: 301 - 309.

Hamadouche, N., Slimani, M. and Avous, A. 2009. Biochemical parameters alterations induced by chronic oral administration of lead acetate in albinos rat. American Journal of Scientific Research, 4: 5-16.

Iheoliaha, J., Iwuogo, M. and Ihedioha, T. 2009. Haemotological and clinical chemistry findings associated with sub-acute contamination of drinking water with varied low percentages of used engine oil. Comp Clin Pathol, 18: 169-176.

Jaeger, J. and Hedegaard, H. 2002. A Review on Liver Function Test: The Danish Hepatitis C Website Available from http://home3.inet.tele.dk/omni/hemochroma tosis_iron.htm.

Jobling, M. 1995. Environmental biology of fishes. 1st ed. Printed in Great britian. Chapman and Hell, London.

Kasprzak, K. 2002.Oxidative DNA and protein damage in metal induced toxicity and carcinogenesis. Free Radical Biol Med, 32: 958-67.

Khadiga, S., Nagat, M., Elsaid, A., Ahmed, M., Abd El-Samei, M. and Eman, M. 2014. Hematological effects of benzene exposure with emphasis on muconic acid as a biomarker in exposed workers. Toxicology, 64:87-98.

Khan, A. and Mudan, S. 2007. Liver regeneration: mechanisms, mysteries and more. ANZ J Surg 77: 9-14.

Kumar, P., Sivaraj, A., Elumalai, E. and Kumar, B. 2009. Carbon tetrachlorideinduced hepatotoxicity in rats-protective role of aqueous leaf extracts of Coccinia grandis. International Journal of Pharma Tech Research, 1(4):1612-1615.

Lowry, O., Resebrough, N., Farr, A. and Randall, R. 1951. J. Biol. Chem, 193: 265.

Mokarizadeh, A., Faryabi, M., Rezvanfar, M., Abdollahi, M. 2015. Comprehensive review of pesticides and the immune dysregulation: mechanisms, evidence and consequences. Toxicol Mech. Methods: 1-21.

Park, H., Oh, J., Roon, S. and Rana, S. 2008. Time dependent gene expression changes in thue liver of mice treated with benzene. Biomarker Insights, 191-201.

Pratibha, K., Anand, V. and Agarwal, R. 2004. Serum adenosine deaminase, S'mucleotidase and malondialdehyde in acute infective hepatitis. Indian Journal of clinical Biochemistry, 19(2): 128-131.

Putte, V. and Part, P. 1982. Oxygen and chromium transfer in prefused gills of rainbow trout, Salmo gairdneri exposed to hexavalent chromium at two different $\mathrm{pH}$ levels. Aquat. Toxicol, 2: 31-45. 
Salah El-Deen, M. 1999. Bioconcentrations of $\mathrm{Hg}, \mathrm{Cd}$ and $\mathrm{Zn}$ in some tissue organs of grass carp, Ctenopharyngodon idella. Egypt. J, 33: 201-218.

Scott-Fordsmand, J. 1997. Toxicity of nickel to soil organisms in Denmark. Rev. Environ. Contam. Toxicol,: 148-1.

Sharma, A. Sharma, V. and Kansal, L. 2010. Amelioration of lead-induced hepatotoxicity by Allium sativum extracts in Swiss albino mice. Libyan Journal of Medicine, 5:20-25.

Smirjakova, S., Ondrasovicova, O., Kaskova, A. and Lakticova, K. 2005. The effect of cadmium and lead pollution on human and animal health. Folior veterinaria, 49(3): S31-S32.

Snyder, R. and Hedli, C. 1993. An overview of benzene metabolism. Environmental Health Perspective, 104(6): 1165-1171.

Tietz, N. 1995. Clinical Guide to Laboratory Tests, 3rd ed.

Uboh, F., Akpanabiatu, M .and Atangwho, I. 2007a. Effect of gasoline vapours on serum lipid profi le and oxidative stress in hepatocytes of male and female rats. Acta Toxicol, 15: 13-18.

Uboh, F., Akpanabiatu, M., Ebong, P. et al. 2007b. Gender differences in the haematotoxicity and weight changes associated with exposure to gasoline vapours in Wistar albino rats. Acta Toxicol, 15: 125-131.

Uboh, F. Akpanabiatu, M., Eteng, M. et al. 2008. Toxicological eff ects of exposure to gasoline vapours in male and female rats. Int $\mathrm{J}$ Toxicol, 4: 40-45.

Uboh, F., Akpanabiatu, M., Atangwho, I., Ebong, P. and Umoh, I., 2009. Effect of vitamin A on weight-loss and Haematotoxicity associated with gasoline vapours exposure in wistar rats. International Journal of Pharmacology, 4(1): 40-45.

Udem, S., Lekwuwa, I. and Udem, N. 2009. Effects of drinking diesel-contaminated water on the hematological and serum biochemical parameters of mice comp clin pathol, DOI. 10.1007/ s 002580-00645-1.

Vinodhini, R. and Narayanan, M. 2008. Bioaccumulation of heavy metals in organs of fresh water fish Cyprinus Carpio (Common carp). Int. J. Environ. Sci. Tech, 5(2): 179-182.

Wan, Y., Chong, L. and Evans, R. 2007. PPAR- $\alpha$ regulates osteoclastogenesis in mice. Nature Med,13(12): 1496-1503.

Wixtrom, R. and Brown, S. 1992. Individual and population exposures to gasoline. J Expo. Anal Environ epidemiol, 2:23-78.

Young, R. 1995.Toxicity profiles summary for nickel and nickel compounds. Website. http://risk.Isd.ornl.gov/tox/profiles/nickel (accessed 0.3.03.2005). 